\title{
GERAKAN ISLAM POLITIK : \\ Problem Ideologi Radikal, Global Jihad, dan Terorisme \\ Keagamaan
}

OZI SETIADI

e-mail : ozisetiadi@gmail.com

\begin{abstract}
Abstrak
Ideologi radikal, global jihad, dan terorisme keagamaan adalah hal yang terkait satu dengan yang lain. Jihad terlahir dari rahim ideologi radikal, begitu pula dengan terorisme yang dapat tumbuh dimana saja dengan doktrin jihad. Agama acapkali dijadikan sebagai alat guna membenarkan dan menjadi jalan bagi para pelaku radikalisme, global jihad, dan terorisme.Keinginan untuk merubah keadaan secara drastis dengan menggunakan berbagai cara telahmenimbulkan promblematika yang signifikan.Aksi-aksi radikalisme, global jihad, dan terorisme berdampak langsung bagi agama dan penganutnya. Agama yang dianut oleh para radikalis, jihadis, dan teroris akan dianggap sebagai agama yang mengajarkan tindakan teror, jihad, dan radikal. Pemeluknya secara luas akan dicap sebagai umat yang intoleran, sebab memaksakan keinginannya dengan menggunakan tiga hal tersebut. Hal ini pun dapat menyebabkan permusuhan dan perpecahan tidak hanya antar umat beragama, tetapi juga internal pemeluk agama. Sebab mayoritas pemeluk agama tidak sependapat dengan apa yang dilakukan oleh orang-orang yang menganggap dirinya mendapat perintah suci dari Tuhan, yakni para radikalis, jihadis, dan teroris.Gerakan-gerakantersebut di atas kemudian dapat dibaca sebagai salah satu bentuk gerakan Islam Politik yang perlu diperhatikan secara serius.
\end{abstract}

Kata Kunci: Ideologi radikal, Global Jihad, Terorisme Keagamaan dan Islam Politik.

\section{A. Pendahuluan}

Dewasa ini, gerakan keagamaan menjadi fokus yang sering dibicarakan dalam kehidupan modern. Bukan karena isu-isu positif seperti penuntasan kemiskinan, pendidikan dan dialog antar agama, melainkan isu radikalisme, jihad dan aksi terorisme. Islam beserta penganutnya, berikut dengan negara-negara Islam di Timur Tengah, seringkali diidentikan sebagai produsen ideologi radikal, global jihad, dan pelaku terorisme. Padahal, hal demikian juga terjadi pada umat dan negara agama lain. Malangnya, pada beberapa negara Islam atau yang berpenduduk mayoritas Muslim sering terjadi konflik berkepanjangan,dan ini 
disebut-sebut sebagai salah satu alasan yang kuat bagi dunia non Islam untuk mengatakan bahwa ideologi radikal, global jihad, dan pelaku terorisme lebih marak di dunia Islam.

Irak dan Suriah adalah negara yang diperebutkan antara pemerintah setempat dengan pasukan jihad yang menamai diri mereka sebagai Islamic State of Iraq and Syiriah (ISIS).Ini adalah salah satu contoh gerakan yang mengatasnamakan agama yang populer belakangan tidak hanya di dua negara tersebut, tetapi juga di dunia internasional. Negari 1001 malam, Mesir, juga menjadi perhatian dunia tatkala berhasil melakukan proses suksesi melalui sistem demokrasi yang menempatkan Mohammad Morsi sebagai presiden menggantikan kepemimpinan Husni Mubarak. Sayangnya, kepemimpinan Morsi tidak berlangsung lama karena digulingkan oleh junta militer dibawah kepemimpinan Al Sisi. Faktor penyebab penggulingan ini salah satunya adalah dominasi Al Ikhwanul Muslimun di pemerintahan Mesir dan keinginan kelompok tersebut untuk mengganti sistem dalam banyak bidang menggantikan peninggalan Husni Mubarak. Militer di bawah kepemimpinan Al Sisi, pengikut Mubarak, serta kelompok sekuler-liberal yang bertentangan dengan Muhammad Morsi dan Al Ikhwanul Muslimun bersatu menumbangkan pemerintahan Morsi. Tidak hanya itu, label organisasi terlarang juga disematkan kepada Al Ikhwanul Muslimun sebagai organisasi radikal yang menentang pemerintahan hasil kudeta.

Arab Saudi juga tak luput dari perhatian. Gerakan ideologis wahabi dapat tumbuh subur di negara tempat dua kota suci umat Islam berada. Bahkan hubungan antara orang-orang yang menganut paham tersebut dengan pemerintah cukup dekat.Tidak jarang pemerintah Saudi "memfasilitasi" penyebaran ideologi pergerakan ini melalui pendirian lembaga-lembaga pendidikan, mesjid dan Musholla, hingga pemberangkatan haji dan umroh bagi "orang-orang terpilih". ${ }^{1}$ Upaya penyebaran paham ini kemudian menghasilkan orang-orang yang disebut sebagai "kelompok domestik wahabi".

Berbeda dengan kelompok Wahabi, Gülen Movementjustru mendapat perlawanan yang amat sengit dari pemerintah negaranya. Gülen Movementatau yang juga dikenal sebagai gerakan hizmetadalah sebuah gerakan yang berasal dari

${ }^{1}$ Di Indonesia, penyebaran paham wahabi salah satunya dapat ditemui pada lembaga pendidikan tinggi yang dikenal dengan Lembaga Ilmu Pengetahuan Islam Arab (LIPIA) yang memberi beasiswa bagi orang-orang Indonesia yang ingin melanjutkan studi pada lembaga tersebut. Kini, LIPIA menjadi salah satu lembaga pendidikan pavorit yang menjadi tujuan alumni pondok pesantren di luar pesantren-pesantren afiliasi Nahdatul Ulama (NU). 
Turki. ${ }^{2}$ Gerakan ini kemudian dicap sebagai gerakan teroris oleh pemerintahan Racep Tayyib Erdogan dan dituduh berupaya untuk melakukan kudeta pada pemerintahannya beberapa tahun yang lalu. Padahal, sebelumnya, kelompok gerakan idologis kultural ini sempat berhubungan dekat dengan Erdoġan ketika ia masih menjadi wali kota Istanbul.

Negara-negara di Asia Tenggara juga mendapat sorotan dari dunia internasional. Ini bermula sejak tahun 2000, dunia menyaksikan kebangkitan radikalisme Islam di Asia Tenggara. Selain kelompok Abu Sayyaf di Filipina selatan yang terlibat, diantaranya, dalam penyanderaan sejumlah warga asing dan kelompok yang disebut Kumpulan Mujahidin Malaysia (KMM).Radikalisme hampir identik dengan kemunculan sejumlah organisasi Islam, di Indonesia seperti Forum Komunikasi Ahlus Sunnah wal Jamaah (FKASWJ), Front Pembela Islam (FPI) dan Majelis Mujahidin Indonesia (MMI). Salah satu organisasi, Jamaah Islamiyah (JI), menyita paling banyak perhatian berkat keterlibatannya dalam sejumlah aksi teror di Indonesia yang menimbulkan banyak korban jiwa. ${ }^{3}$

Meski tak banyak menyita perhatian, gerakan keagamaan lain juga terjadi pada umat beragama dan negara di luar Islam. Dua agama samawi, yakni Yahudi dan Nasrani juga memiliki penganut yang radikal. Perlakuan umat Yahudi yang mengutuk Maimondes dan kritik pedas umat Nasrani atas Thomas Aquinas yang dianggap kafir menjadi bukti bahwa kelompok radikal tetap saja ada pada umat beragama. Pembantaian etnis Rohingya di Myanmar yang juga melibatkan kaum agamawan Budha seolah membuktikan statmen di atas. Walaupun mereka berdalih terdapat perlawanan yang dilakukan oleh kelompok kecil Rohingya, akan tetapi tindakan kekerasan atas nama agama tetap saja tidak dapat dibenarkan. Karena umat manusia secara internasional memiliki hak, utamanya adalah hak untuk memperoleh kehidupan!

Banyaknya aksi terorisme keagamaan yang muncul, pemahaman terhadap global jihad, serta penyebaran ideologi radikal yang tak terbendung memberikan perhatian khusus, utamanya bagi penulis, untuk melakukan kajian terhadapnya.

${ }^{2}$ Gülen Movement atau yang juga dikenal sebagai gerakan hizmet adalah sebuah gerakan transnasional yang diinspirasi oleh Fethullah Gülen yang berasal dari Turki. Mengusung tema memerang kemiskinan, kebodohan dan konflik sebagai ide utama, gerakan ini kemudian meluas dan berada pada lebih dari 120 negara. Di Indonesia, gerakan ini telah berhasil mendirikan 9 sekolah bertaraf internasional, lembaga kursus dan pelatihan, lembaga dialog, lembaga ekonomi, dan lembaga kemanusiaan.

${ }^{3}$ Eric Hiariej, “Aksi Dan Identitas Kolektif Gerakan Islam Radikal Di Indonesia," dalam http://mprk.ugm.ac.id/wp-content/uploads/2014/06/Hiariej-Aksi-dan-Identitias-KolektifGerakan-Islam-Radikal-di-Indonesia.pdf (diakses pada tanggal 07 September 2017) 
Oleh karena itu, pada makalah ini akan dibahas bagaimana problem yang adasebagai akibat dari munculnya gerakan keagamaan yang mengusung ideologi radikal, global jihad, dan kemudian bertransformasi menjadi sebuah aksi terorisme keagamaan. Hal ini dianggap penting sebab ketiga tema di atas sangat terkait dengan situasi dan kondisi keamanan, serta keagamaan, khususnya Islam yang senantiasa dipojokkan dan dituding sebagai agama produsen pelaku tindak kekerasan.

\section{B. Faktor Penyebab Lahirnya Islam Politik: Ideologi Radikal, Global Jihad dan Terorisme Keagamaan}

Kemiskinan adalah masalah yang sering dikaitkan sebagai penyebab munculnya orang-orang yang ikut dalam ideologi radikal, jihad dan terorisme. Filsuf terkenal Aristoteles pernah mengemukakan bahwa kemiskinan adalah induk dari segala kriminalitas. Kemiskinan identik dengan perbudakan, dan perbudakan menutup kemungkinan terjadinya mobilitas sosial vertikal. Oleh sebab itu, ia menyebut budak tidak akan mungkin bisa berubah status menjadi aristokrat. ${ }^{4}$ Ini berarti kalangan proletar akan tetap berada pada lingkungan kemiskinan yang tidak mudah untuk dirubah.

Kemiskinan menjadi sebuah budaya yang telah mendarah-daging. Bila merujuk pada pendapat Aristoteles, merubahnya amatlah sangat sulit. Hal ini disebabkan kemiskinan tumbuh dan berkembang dengan adanya seperangkat kondisi yang ada pada masyarakat. Kondisi itu adalah; 1) Sistem ekonomi uang, buruh upahan dan sistem produksi untuk keuntungan; 2) tetap tingginya tingkat pengangguran dan setengah pengangguran bagi tenaga tak terampil; 3) rendahnya upah buruh; 4) tidak berhasilnya golongan berpenghasilan rendah meningkatkan organisasi sosial, ekonomi dan politiknya secara sukarela maupun atas prakarsa pemerintah; 5) sistem keluarga bilateral lebih menonjol dari pada sistem unilateral, dan akhirnya; 6) kuatnya seperangkat nilai-nilai pada kelas yang berkuasa yang menekankan penumpukan harta kekayaan dan adanya kemungkinan mobilitas vertikal, dan sikap hemat, serta adanya anggapan bahwa rendahnya status ekonomi sebagai hasil ketidaksanggupan pribadi atau memang

\footnotetext{
${ }^{4}$ Ahmad Suhelmi, Pemikiran Politik Barat: Kajian Sejarah Perkembangan Pemikiran Negara, Masyarakat dan Kekuasaan (Jakarta: PT. Gramedia Pustaka Utama, 2004), Cet. II, 29.
} 
pada dasarnya sudah rendah kedudukannya. ${ }^{5}$ Kondisi inilah yang menyebabkan kalangan proletar sulit untuk keluar dari jurang kemiskinan.

Masyarakat miskin seperti mengidap penyakit yang mengakibatkan tidak berlangsungnya fungsi-fungsi psikis dan fisis dengan baik. Terdapat kelainan dan penyimpangan atas mereka yang mengakibatkan kerusakan dan bahaya pada organ atau tubuh, sehingga bisa mengancam kehidupan. ${ }^{6}$ Secara sosial, penyakit ini tidak hanya mengancam diri yang menderitanya, tetapi juga keberlangsungan bagi kehidupan orang lain. Kriminalitas menjadi salah satu dampak yang diakibatkan dari penyakit yang ada pada diri masyarakat miskin. Lebih dari itu, berbagai aksi radikalisme dan terorisme dapat bermula karena masyarakat mengidap sebuah penyakit yang disebut dengan kemiskinan.

Keterlibatan masyarakat miskin dalam musyawarah-musyawarah strategis juga sangat terbatas, sehingga berakibat pada penganggaran yang tidak pro terhadap mereka. Joe Fernandez menyebut persoalan penganggaran harus ditinjau lebih jauh dari paradigma ekonomi politik yang dianut oleh para penyusun anggaran. ${ }^{7} \mathrm{Hal}$ ini diperlukan agar masyarakat miskin dapat merasakan dampak langsung yang baik dari pembangunan, bukan menjadi kambing hitam tatkala kekerasan, kriminalitas, hingga radikalisme dan terorisme terlahir karenanya. ${ }^{8}$

Mantan Presiden Amerika Serikat George W. Bush dan mantan PM Inggris Tony Blairmemang menyebut kemiskinan sebagai induk dari kriminalitas. Keduanya sependapat dengan apa yang dikemukakan oleh Aristoteles. Akan tetapi, pendapat ini tidak selamanya dibenarkan oleh para ilmuan.Ada pula yang mengatakan bahwa kemiskinan tidak identik dengan keterlibatan seseorang dalam ideologi radikal, global jihad, dan terorisme keagamaan. Penelitian yang dilakukan oleh Alan Krueger dan Jitka Maleckova (2002, 2003) membuktikan hal yang

\footnotetext{
${ }^{5}$ Oscar Lewis, "Kebudayaan Kemiskinan," dalam Parsudi Suparlan, Kemiskinan Di Perkotaan (Jakarta: Yayasan Obor Indonesia, 1995), 5.

${ }^{6}$ Kartini Kartono, Patologi Sosial Gangguan-Gangguan Kejiwaan (Jakarta: Rajawali Pers, 2010), 13.

${ }^{7}$ Baca Joe Fernandez, “Anggaran Pro Kaum Miskin: Konsep dan Praktik," dalam Anggaran Pro-Kaum Miskin: Sebuah Upaya Menyejahterakan Kaum Miskin, Abdul Waidl dkk. (Jakarta: Pustaka LP3ES, 2009), 3-30.

${ }^{8}$ Nurcholis Madjid menyebut bahwa kemiskinan akan membuat manusia terhalang dari usaha-usaha peningkatan dirinya menuju kepada harkat dan martabat kemanusiaannya yang lebih tinggi. Sebab kemiskinan dan kemelaratan membuat seseorang lebih terpusat pada usaha-usaha mempertahankan hidup. Lihat Nurcholis Madjid, "Kebebasan Nurani dan Kemanusiaan Universal sebagai Pangkal Demokrasi, Hak Asasi dan Keadilan,” dalam Elza Peldi Taher, Demokratisasi, Politik, Budaya dan Ekonomi: Pengalaman Indonesia Masa Orde Baru (Jakarta: Yayasan Paramadina, 1994), 124.
} 
berbeda. Mereka mengungkapkan bahwa pelaku terorisme justru berasal dari kalangan kelas menengah dan berpendidikan tinggi, sehingga kemiskinan bukanlah satu-satunya faktor yang menjadi titik tolak aksi terorisme, apalagi jihad dan ideologi radikal. ${ }^{9}$ Oleh karena itu, melalui dua ide tersebut dapat dinyatakan bahwa radikalisme, globa jihad, dan terorisme beradaptasi kepada subjek penganutnya.

Ketidakadilan, ${ }^{10}$ keinginan untuk mengimplementasikan ajaran agama secara utuh, ${ }^{11}$ dan kekuasaan merupakan beberapa faktor yang menyebabkan munculnya aksi-aksi terorisme. Hal inilah yang kemudian memunculkan aksi kolektif karena para aktivis yang merasa terganggu merasa perlu melakukan tindakan bersama dalam mengatasi suatu hal yang menurut mereka sebagai persoalan.Meski terdapat banyak faktor yang menjadi penyebab munculnya terorisme, namun ketidakadilan menjadi faktor yang cukup kuat dalam mendorong aksi terorisme. Bahkan ini dapat berujung pada sebuah benturan, yang dalam istilah Samuel

\footnotetext{
${ }^{9}$ Maarif Institute For Cultural Humanity, Dalam http://maarifinstitute.org/maariffellowship/?gclid=CPy3qayMktYCFdMRaAod6VwNpA (diakses pada tanggal 07 September 2017)

${ }^{10}$ Waldstreicher menjelaskan faktor-faktor pengasingan dan urbanisasi yang mendasari teori orang marjinal, yang mana oleh intelektual emansipasi Yahudi telah lama dipraktikkan,digabungkan dengan "perintah Torah dan Talmud ... sistem kepercayaan mesianis, tradisi tzedaka (bukan hanya amal, tapi keadilan dan keadilan terhadap orang lain, saling membantu, dan tanggung jawab komunal. Robert Park, "Human Migration and the Marginal Man," American Journal of Sociology 33 (1928), 881-893; Milton Gordon, "Marginality and the Jewish Intellectual," Human Nature, Class and Ethnicity (New York: 1978), pp. 279-295 dalam David Waldstreicher, "Radicalism, Religion, Jewishness: The Case of Emma Goldman," American Jewish History 80, no. 1 (1990): 75.Leon P. Baradat (1994: 16) mengingatkan bahwa dalam suatu sistem politik, ada kelompok radikal yang menginginkan perubahan secara komprehensif atas sistem yang berlaku (status quo). Lihat Maarif Institute For Cultural Humanity,dalam http://maarifinstitute.org/maariffellowship/?gclid=CPy3qay MktYCFdMRaAod6VwNpA (diakses pada tanggal 07 September 2017).

${ }^{11}$ Mayoritas tulisan yang membahas perkembangan kontemporer radikalisme Islam di Asia Tenggara juga memahami aksi para aktivis Muslim garis keras sebagai upaya mewujudkan tujuan, yakni penerapan Shari'a, pendirian sebuah negara Islam atau pendirian sebuah khilafah. Lihat dalam Eric Hiariej, "Aksi Dan Identitas Kolektif Gerakan Islam Radikal Di Indonesia," dalam http://mprk.ugm.ac.id/wpcontent/uploads/2014/06/Hiariej-Aksi-dan-Identitias-Kolektif-Gerakan-Islam-Radikal-diIndonesia.pdf (diakses pada tanggal 07 September 2017).
} 
Huntington disebut clash of civilization(benturan peradaban)..$^{12}$ Oleh karenanya, keadilan berperan penting dalam membina keharmonisan peradaban.

Demokrasi menjadi sebuah sistem pemerintahan yang dituntut paling bertanggung jawab dalam munculnya ketidakadilan. Nilai universal demokrasi yang dikenal sebagai liberte (kebebasan) membuat sebagian orang bebas melakukan apa yang dikehendaki olehnya, selama tidak berbenturan dengan sistem hukum. Kapitalis dengan ideologi kapitalisme telah memanfaatkan nilai liberte ini. Kemunculan stationary bandits dan roving bandits adalah bukti bagaimana ketidakadilan bisa terjadi di berbagai negara yang menganut sistem demokrasi. Multy National Company (MNC),sebagai salah satu contoh stationary bandits, telah bercokol cukup lama menguras segala sumber daya yang ada, tidak hanya sumber daya alam, tetapi juga sumber daya politik. ${ }^{13}$ Hal inilah kemudian yang menyebabkan ketidakadilan semakin terasa karena sumber daya - sumber daya tersebut hanya dikuasai oleh elit-elit tertentu.Sedang masyarakat miskin hanya sebagai pelengkap suara tatkala dibutuhkan, dan dengan mudah diarahkan oleh kemampuan modal yang tinggi dari korporasi tersebut.

Penguasaan atas berbagai sumber daya mendapat legitimasi dari suara mayoritas yang memilih elit politik untuk menduduki posisi-posisi tertentu. Celakanya, hal ini dapat berakibat pada munculnya "tirany mayoritas" seperti yang dikemukakan oleh Alexis de Tochueville, ${ }^{14}$ yang mana mayoritas elit terpilih dari mayoritas suara yang diarahkan. Penguasaan sumber daya oleh tirani tersebutlah yang kemudian menjadi salah satu faktor pemicu munculnya berbagai gerakan yang mengatasnamakan agama atau ideologi tertentu yang berkeinginan untuk mengganti dan menghapus ideologi serta sistem kenegaraan, termasuk menghilangkan dua bandit demokrasi yang disebutkan di atas. Hal ini dilakukan dengan berbagai aksi yang "dianggap pantas" oleh gerakan tersebut.

David Wright-Neville telah membedakan tiga macam agenda aksi (gerakan), khususnya bagi gerakan yang dilakukan oleh kelompok-kelompok Islam; yakni1) aksi yang bertujuan sekedar merubah kebijakan politik agar bernuansa Islami, 2) yang bertujuan bukan saja untuk merubah kebijakan, tapi juga untuk mengganti

${ }^{12}$ Joshua D. Hendrick, "Global Islam and the Modern World: Transnasional Muslim Social Movements and the Movement of Fethullah Gülen, a Comparative Approach," dalam Islam in the Contemporary World-2, (New Jersey: Tughra Books, 2009), 124.

${ }^{13}$ Baca I. Wibowo, Negara dan Bandit Demokrasi (PT. Kompas Media Nusantara, 2011),27-35.

${ }^{14}$ Nurcholis Madjid, "Kebebasan Nurani dan Kemanusiaan Universal sebagai Pangkal Demokrasi, Hak Asasi dan Keadilan," dalam Elza Peldi Taher, Demokratisasi, Politik, Budaya dan Ekonomi: Pengalaman Indonesia Masa Orde Baru, 136. 
hirarki politik yang lebih berpihak pada umat Islam, dan 2) yang bertujuan untuk melakukan perubahan radikal terhadap tatanan sosial yang ada dengan menggunakan kekerasan. ${ }^{15}$ Meski tiga macam agenda aksi yang dirumuskan oleh David Wright-Neville ini digunakan untuk mengklasifikasi aksi Muslim di Malaysia dan Indonesia, namun setidaknya hal ini dapat memberikan gambaran akan gerakan umat Muslim secara umum.

Ideologi radikal, global jihad dan terorisme, dalam konteks umat Muslim, diidentikan dengan semangat memunculkan nagara Islam, atau yang lebih populer dengan istilah khilafah al Islamiyyah. Meski mayoritas menyebutkan demikian, akan tetapi tidak semua orang bersepakat bahwa radikalisme, global jihad dan terorisme hanya memiliki satu tujuan tersebut. Forum Komunikasi Ahlu Sunnah Wal Jamaah (FKASWJ) lebih menitikberatkan pentingnya membentuk komunitas Islam yang taat ketimbang mendirikan sebuah negara Islam. ${ }^{16}$ Ini menandakan adanya sebuah pemaknaan yang relatif moderat daripada maksud dan tujuan gerakan radikal, jihad, serta terorisme. Meski juga ada anggapa lain, seperti yang dikemukakan oleh Afrizal bahwa Islam bagi sebagian kalangan Barat dianggap sebagai suatu kekuatan yang sangat membahayakan eksistensi dan pengaruh Barat (Kristen) di berbagai belahan dunia. ${ }^{17}$ Artinya, kompetisi umat Islam dengan umat agama lain menjadi sesuatu yang tidak dapat dihindari, dan dapat dilakukan dengan cara apa pun. ${ }^{18} \mathrm{Hal}$ inilah kemudian yang juga turut melatarbelakangi berkembangnya ideologi radikal, global jihad dan terorisme.

Joseph Rudyard Kipling (1865-1936) bahkan menyebutkan diktum yang terkenal terkait dengan hubungan antara Barat dan Timur. Ia menyebutkan bahwa "Timur adalah Timur, Barat adalah Barat, dua belahan ini tidak akan pernah

\footnotetext{
${ }^{15}$ Pembedaan aksi tersebut dilakukan untuk mengklasifikasikan aktivis Muslim di Malaysia dan Indonesia menjadi activist, militant dan terrorist. Eric Hiariej, "Aksi Dan Identitas Kolektif Gerakan Islam Radikal Di Indonesia," 1 dalam http://mprk.ugm.ac.id/wp-content/uploads/2014/06/Hiariej-Aksi-dan-Identitias-KolektifGerakan-Islam-Radikal-di-Indonesia.pdf (diakses pada tanggal 07 September 2017).

${ }^{16}$ Eric Hiariej, “Aksi Dan Identitas Kolektif Gerakan Islam Radikal Di Indonesia," 13.

${ }^{17}$ Jhon Afrizal, "Gerakan Sosial Politik Islam Dunia (Asas Perubahan Skenario Politik Negara)," 138, Jurnal Sosial Budaya Vol. 9 No. 1 Januari-Juli 2012 dalam https://media.neliti.com/media/publications/40436-ID-gerakan-sosial-politik-islamdunia-asas-perubahan-skenario-politik-negara.pdf (diakses pada tanggal 07 September 2017).

${ }^{18}$ Kompetisi (Persaingan) bermula dari pengutamaan kepentingan perorangan (selfinterest - pamrih pribadi) sebagai ciri utama paham liberalisme/individualisme. Baca lebih lajut Sri-Edi Swasono, Keindonesiaan: Demokrasi Ekonomi, Keberdaulatan, dan Kemandirian (Yogyakarta: Ust Press, 2015), 30
} 
bertemu."19 Timur yang dimaksud adalah mewakili dunia Islam, sedang Barat mewakili dunia non Muslim. Meski kerjasama peradaban dapat terjalin, Kipling sadar benar bahwa kerjasama itu berdasarkan pada kepentingan masing-masing. Dan kerjasama yang dijalin atas dasar kepentingan tidak bersifat abadi, sehingga kelanggengan hanya terjadi sejauh mana kepentingan masing-masing dapat terakomodir.

Hiariej menyebutkan kelompok-kelompok di atas bisa saja menggunakan kekerasan dan serangan mematikan, namun juga tidak menutup kemungkinan melakukan pawai massa dan protes damai. ${ }^{20}$ Meski bukan sebagai bentuk radikalisme, namun aksi bela Islam, bela ulama, bela Al-Quran di Indonesia yang terakumulasi pada aksi damai 212 pada 2 Desember 2016, hingga reuni 212 pada 2 Desember 2017 yang melibatkan berbagai ormas keagamaan Islam menjadi salah satu bukti bahwa kelompok radikal juga melakukan berbagai aksi, sekali lagi, yang "dianggap pantas" dan melakukan berbagai hal untuk mencapai tujuan mereka.

Perlu diketahui, sebagai benang merah tentang aksi atas yang dilakukan oleh kelompok-kelompok di atas, bahwa para aktivis melakukan tindakan yang berbeda dengan kalangan radikalisme, fundamentalisme, dan terorisme.Yakni yang melakukan tindakan bukan hanya sekedar untuk mewujudkan ideologi-ideologi mereka, sebagaimana seorang fundamentalis, bukan hanya mewujudkan kefundamentalis-an, melainkan adalah bagian dari aksi fundamentalisme itu sendiri. Landasan yang fundamental seperti inilah yang akan memunculkan gerakan ideologi radikal, global jihad, dan terorisme yang kemudian akan di bahas pada pembahasan selanjutnya.

\section{Ideologi Radikal}

Radikal, radikalisme dan radikalisasi adalah kata yang mirip, namun memiliki makna yang berbeda. Radikal sering kali dikaitkan dengan cara berpikir. Berpikir radikal ialah berpikir mendalam sampai ke akar. Sedangkan radikalisasi adalah proses menjadi radikal. Akan tetapi, makna radikal akan menjadi berbeda ketika didekatkan dengan ideologi, menjadi ideologi radikal.Ideologi radikal dapat melahirkan sebuah paham yang dikenal dengan radikalisme. Radikalisme adalah

\footnotetext{
${ }^{19}$ Sri-Edi Swasono, Keindonesiaan: Demokrasi Ekonomi, Keberdaulatan, dan Kemandirian, 30.

${ }^{20}$ Eric Hiariej, “Aksi Dan Identitas Kolektif Gerakan Islam Radikal Di Indonesia,” 14.
} 
sebuah paham tua yang hadir setua usia manusia. ${ }^{21}$ Paham atau aliran ini menginginkan perubahan atau pembaharuan sosial dan politik dengan cara kekerasan atau drastis. ${ }^{22}$

Fathorrahman Ghufron menyebut setidaknya ada tiga gejala yang dapat ditengarai dari paham radikalisme. Pertama, merespons terhadap kondisi sosialpolitik maupun ekonomi yang sedang berlangsung dalam bentuk penolakan dan perlawanan. Terutama aspek ide dan kelembagaan yang dianggap bertentangan dengan keyakinannya. Kedua, dari penolakan berlanjut kepada pemaksaan kehendak untuk mengubah keadaan secara mendasar ke arah tatanan lain yang sesuai dengan cara pandang dan ciri berpikir yang berafiliasi kepada nilai-nilai tertentu, semisal agama maupun ideologi lainnya. Ketiga, menguatkan sendi-sendi keyakinan tentang kebenaran ideologi yang diyakininya lebih unggul daripada yang lain. ${ }^{23}$ Keyakinan terhadap ideologi yang paling benar inilah kemudian yang menimbulkan perasaan bahwa kelompok radikalisme terpilih diantara umat agamalain guna melakukan apa yang mereka sebut sebagai misi suci. Ini dikuatkan dengan anggapan bahwa para radikalis telah memiliki keabsahan yang kuat atas apa yang mereka lakukan.Keyakinan ini yang kemudian menurut Rodin selalu dikaitkan dengan menghadirkan nama Tuhan. ${ }^{24}$ Padahal keyakinan terhadap ketuhanan (keimanan) memiliki tujuan yang mulia lebih dari sekedar alat legitimasi tindakan.

\footnotetext{
${ }^{21}$ Baca Rakhmatulloh, "Sejarah Munculnya Radikalisme," Kamis, 12 Mei 2016, 17:29 WIB dalam https://nasional.sindonews.com/read/1107997/14/sejarah-munculnyaradikalisme-1463048982 (diakses pada tanggal 11 September 2017).

${ }^{22}$ Lihat dalam Kamus Besar Bahasa Indonesia (KBBI) Online dalam https://kbbi.web.id/radikalisme (diakses pada tanggal 11 September 2017). Nasution mengemukakan bahwa radikalisme adalah gerakan yang berpandangan kolot dan sering menggunakan kekerasan dalam mengajarkan keyakinan mereka. Lihat dalam Sun Choirol Ummah, "Akar Radikalisme Islam Di Indonesia," 114, Humanika, No. 12/Sept. 2012 dalam https://media.neliti.com/media/publications/18118-ID-akar-radikalisme-islam-diindonesia.pdf (diakses pada tanggal 11 September 2017).

${ }^{23}$ Fathorrahman Ghufron, "Radikalisme dan Politik Identitas,"05 Mei 2017, 1917 WIB dalam http://nasional.kompas.com/read/2017/05/05/19170871/radikalisme.dan.politik.identita s (diakses pada tanggal 11 September 2017). Berbeda dengan pendapat-pendapat sebelumnya yang mengemukakan kemiskinan dan ketidakadilan sebagai akar dari kemunculan radikalisme, Ghufron lebih mengedepankan aspek sosiologis dari pada indivialistik.

${ }^{24}$ Dede Rodin, "ISLAM DAN RADIKALISME: Telaah atas Ayat-ayat "Kekerasan" dalam al-Qur'an,” ADDIN, Vol. 10, No. 1, Februari 2016 dalam http://journal.stainkudus.ac.id/index.php/Addin/article/download/1128/1057 (diakses pada tanggal 11 September 2017).
} 
Nurcholis Madjid menyebut bahwa keimanan dan ketaqwaan melengkapi seseorang dengan tujuan hidup yang tinggi, yang transendental, yang mengatasi tujuan-tujuan hidup duniawi, yang terrestrial. Tetapi keimanan dan ketaqwaan selamanya bersifat pribadi -justru yang paling pribadi- maka ia tidak cukup guna menciptakan masyarakat yang membahagiakan semuanya. Keimanan dan ketaqwan itu harus diterjemahkan ke dalam tindakan-tindakan nyata dalam masyarakat, berupa tindakan-tindakan kebajikan yang sejalan dengan semangat kemanusiaan universal, sehingga berdampak pada kehidupan bersama. ${ }^{25}$ Persoalan kemudian adalah adanya subjektifitas dalam penafsiran keimanan. Interpretasi keimanan sangat bergantung pada siapa yang menafsirkannya, sehingga orangorang yang memiliki kecenderungan ekslusif dan termarjinalkan akan menafsirkan keimanan dalam tindakan nyata yang dianggapnya benar. Padahal belum tentu agama membenarkan tindakan yang dilakukan olehnya, sebab terdapat sistem hukum (aturan) yang secara tegas termuat dalam agama.

Mengutip pendapat Hans Kelsen, Mahfud MD, menjelaskan bahwa siapapun yang menjalankan suatu fungsi yang ditentukan oleh suatu tata hukum adalah organ atau lembaga. Jadi, organ atau lembaga bukan hanya organisasi, tetapi juga orang atau pejabat yang memegang jabatan berdasar hukum asal fungsinya jelas yakni menciptakan norma (normcreating) dan/atau menjalankan norma (norm applying).$^{26}$ Inilah yang dilakukan pula oleh kalangan radikalis, yaitu menciptakan dan menjalankan aturan hukum yang dianggap benar olehnya, dengan menjadikan apapun sebagai alat legitimasi, termasuk agama.

Agama sering kali dijadikan alat guna membenarkan dan menjadi jalan bagi radikalisme. Ini disebabkan agama merupakan sebuah keyakinan yang dianut oleh mayoritas umat di dunia, sehingga mudah sekali menggunakan agama sebagai alat legitimasi bagi perilaku apapun, apalagi radikalisme. ${ }^{27}$ Malangnya, menjadikan agama sebagai alat tentunya akan menyebabkan agama tersebut ditinggalkan. Bukan karena agama tidak menjadi solusi atas berbagai macam persoalan,

\footnotetext{
${ }^{25}$ Nurcholis Madjid, "Kebebasan Nurani dan Kemanusiaan Universal sebagai Pangkal Demokrasi, Hak Asasi dan Keadilan," dalam Elza Peldi Taher, Demokratisasi, Politik, Budaya dan Ekonomi: Pengalaman Indonesia Masa Orde Baru, 130.

${ }^{26}$ Moh. Mahfud MD, "Dinamika Konstitusionalisme dan Konstitusi dalam ketatanegaraan di Indonesia," dalam Membangun Negeri, Memihaki Bangsa Sendiri, edt. R. Siti Zuhro dan Zainuddin Maliki (Surabaya: Hikmah Press, 2017), 313.

${ }^{27}$ Meski masyarakat komunis beranggapan agama adalah candu, sehingga tidak memerlukan adanya agama tersebut, akan tetapi komunisme menjadi ideologi yang mereka yakini dan dijalankan dalam praktik kehidupan mereka. Artinya, ketidakpercayaan terhadap agama, mengalihkan mereka kepada percaya terhadap komunisme.
} 
melainkan lebih kepada isu kekerasan, konflik dan permusuhan seringkali bermuara pada agama. Setidaknya hal inilah yang dikemukakan oleh Harris yang mana agama sangat potensial menyulut api kekerasan. ${ }^{28}$ Yakni, penggunaan agama sebagai alat legitimasi perilaku kekerasan. Oleh karenanya, radikalisme tidak hanya hadir pada satu agama, melainkan pada berbagai agama di dunia ini terdapat kelompok-kelompok tertentu yang berpemahaman radikal.

Orang-orang yang menjadikan radikalisme sebagai paham akan mewariskan apa yang diyakininya kepada orang lain. Ini tidak terbatas pada satu aliran kepercayaan atau agama tertentu, tetapi pada seluruh umat manusia radikalisme dapat terjadi. Investasi yang dilakukan oleh para pendahulu gerakan dalam bentuk ideologi telah beralangsung lama. Bukan satu atau dua tahun, bahkan lebih mengingat sebuah ideologi benar akan menjelma sebagai keyakinan dalam waktu yang tidak sebentar. Pepatah China dirasa cukup untuk menggambarkan bagaimana radikalisme itu menyebar pada pribadi-pribadi tertentu, bahwa "Apabila kamu ingin mendapatkan hasil dalam satu tahun, tanamlah sayuran. Jika kamu ingin mendapatkan hasil dalam sepuluh tahun, tanamlah buah-buahan. Tetapi, jika kamu ingin mendapatkan hasil dalam seratus tahun atau lebih, tanamlah manusia. ${ }^{.29}$ Pepatah ini menjelaskan manusia adalah subjek sekaligus objek penyebaran radikalisme. Sayangnya, radikalisme seringkali diidentikan dengan agama Islam, sehingga Islam kerap dianggap sebagai produsen orang-orang yang berpaham radikal.

Islam merupakan salah satu agama yang acapkali dipojokkan oleh masyarakat Barat dan dituduh sebagai "akar" dari radikalisme dan terorisme. ${ }^{30}$ Peristiwaperistiwa kekerasan yang terjadi di Timur Tengah, seperti perlakuan tentara ISIS terhadap warga sipil yang ditawan,pun dijadikan sebagai alat bukti yang seolah membuktikan kebenaran ungkapan tesebut. Kebenaran atas tuduhan ini didukung pula dengan adanya oknum-oknum umat Islam yang memiliki pola pikir (mindset)

\footnotetext{
${ }^{28}$ Baca Harris, The End of Faith: Religion: Terror and the Future of Reason dalam Sun Choirol Ummah, "Akar Radikalisme Islam Di Indonesia," Humanika, No. 12/Sept. 2012 dalam https://media.neliti.com/media/publications/18118-ID-akar-radikalisme-islam-diindonesia.pdf (diakses pada tanggal 11 September 2017).

${ }^{29}$ Baca Hasbullah Thabrany, dkk, Sakit, Kemiskinan dan MDGs (Jakarta: Kompas Media Nusantara, 2009), 27.

${ }^{30}$ Upaya pemojokkan Islam banyak dilakukan oleh masyarakat Barat melalui media massa. Akan tetapi, upaya tersebut menjadi sesuatu yang paradoks. Hal ini dikarenakan upaya pemojokan tersebut justru berimbas pada masuknya agama Islam dalam ruang publik di negara-negara Barat akibat rasa ingin tahu yang timbul di kalangan masyarakat barat karena upaya pemojokan yang dilakukan. Lihat dalam Sun Choirol Ummah, "Akar Radikalisme Islam Di Indonesia," 113.
} 
ekstrem, sehingga memilih jalan pintas untuk mengubah sebuah tatanan sosial yang ada dengan sistem yang mereka kehendaki. Muh. Tahir al-Qadrimenjelaskan tentang mindset radikal dalam Islam yang dapat dilihat, setidaknya, dari tiga hal. Pertama, meyakini pandangan mereka sebagai reprentasi Islam yang sebenarnya. Kedua, Muslim lain yang tidak setuju, dan seluruh penguasa muslim, tidak sesuai dengan hukum Islam. Ketiga, pemerintah adalah perpaduan dari kemungkaran dan kebaikan, kekafiran dan kemusyrikan atau kesesatan. ${ }^{31}$ Tiga hal inilah kemudian yang dapat menjelaskan bagaimana sesungguhnya pola pikir umat radikal dalam Islam.

Grand Mufti/Ketua Dewan Ulama Senior, Syaikh Abdul Azis bin Abdullah, dari kerajaan Arab Saudi pernah menegaskan bahwa pemikiran radikalisme dan terorisme sama sekali bukan dari Islam, bahkan merupakan musuh Islam nomor satu. Orang-orang yang menganut ideologi radikalisme disebut sebagai perpanjangan Khawarij yang merupakan kelompok pertama yang keluar dari Islam karena sikap mereka yang mengkafirkan kaum muslim lainnya. Fokus pada kelompok Khawarij bukan tanpa alasan. Sejarah telah membuktikan bagaimana kelompok tersebut keluar dari pertikaian yang terjadi antara Ali bin Abi Thalib dengan Muawiyyah bin Abi Sofyan yang berperang memperebutkan jabatan khalifah. Perebutan kekuasaan inilah kemudian menyebabkan kelompok yang dahulu hidup rukun bersama umat Islam yang lainini keluar dan pada akhirnya mengutuk kelompok yang saling bertikai serta menganggapnya bukan bagian dari Islam. ${ }^{32}$ Oleh karenanya, mereka disebut sebagai khawarij.

Badan Nasional Penanggulangan Terorisme (BNPT) Republik Indonesia menyebut Radikalisme adalah embrio bagi lahirnya terorisme. Ciri-ciri sikap dan paham radikal seolah membuktikan kebenaran anggapan tersebut. BNPT menyebut setidaknya terdapat empat ciri sikap dan paham radikal yang dapat dikenali, yakni intoleran, fanatik, ekslusif dan revolusioner. ${ }^{33}$ Keempat ciri ini

\footnotetext{
${ }^{31}$ Baca dalam Hamidin, "Memahami Radikalisasi sebagai Proses Sosial," dalam https://damailahindonesiaku.com/memahami-radikalisasi-sebagai-proses-sosial-bagian2.html (diakses pada tanggal 11 September 2017).

${ }^{32}$ M.A. Shaban menyebut aliran garis keras (radikalisme) dengan sebutan neo-Khawarij. Sedangkan Harun Nasution menyebutnya dengan sebutan Khawarij abad kedua puluh satu (abad ke-21) karena memang jalan yang ditempuh untuk mencapai tujuan adalah dengan menggunakan kekerasan sebagaimana dilakukan Khawarij pada masa pasca-tahkim. Lihat dalam Sun Choirol Ummah, "Akar Radikalisme Islam Di Indonesia," 114. Baca juga crisis of moslem history.

${ }^{33}$ Badan Nasional Penanggulangan Terorisme (BNPT), "Strategi Menghadapi Paham Radikalisme Terorisme - ISIS," 1, dalam http://belmawa.ristekdikti.go.id/wp-
} 
memiliki kedekatan yang cukup erat bila disandingkan dengan para pelaku terorisme.

Keberadaan ideologi radikal bila dibiarkan akan berakibat pada munculnya aksi terorisme. Ini disebabkan akan sangat sulit untuk merubah masyarakat yang luas dalam waktu singkat, sementara keinginan melakukan perubahan itu sangat mendesak. Maka, kelahiran terorisme adalah sebuah keniscayaan bagi pemeluk ideologi radikal.

\section{Global Jihad}

Implementasi ideologi radikal dapat dilihat dengan adanya sebuah gerakan yang disebut dengan global jihad. Global jihad erat kaitannya dengan gerakan Islam transnasional, meski tidak menjadi monopoli umat Islam. Ini disebabkan Islam diyakini sebagai agama yang universal, sehingga memungkinkan adanya upaya global dalam mendakwahkannya.

Jihad (جهاد) merupakan sebuah istilah dalam Bahasa Arab yang berarti berjuang dengan bersungguh-sungguh. Istilah ini kemudian dipahami sempit oleh sebagian kalangan yang menganggap jihad hanya sebatas pada aksi kekerasan fisik bagi orang-orang di luar umat Muslim. Terorganisir dan muncul sebagai sebuah gerakan yang tidak mudah dibendung. ${ }^{34}$

Mewabahnya gerakan Jihad dipicu oleh perang Afganistan. Perang ini kemudian melahirkan dua kelompok yang disebut sebagai motor penggerak jihadi. Kedua kelompok gerakan ini adalah gerakan Ikwan sayap kanan dan salafi sayap radikal. ${ }^{35}$ Tokoh pemikir gerakan ini adalah Abdullah Azzam, Aiman Zawahiri, dan Sheikh Abu Muhammad Al Maqdisy. Sedang operator utamanya adalah Usamah bin Laden. ${ }^{36}$ Pertemuan antara pengikut ikhwan sayap kanan dan salafi radikal

content/uploads/2016/12/Strategi-Menghadapi-Paham-Radikalisme-Terorisme.pdf (diakses pada tanggal 11 September 2017).

${ }^{34}$ Lihat lebih lanjut defenisi jihad dalam Kamus Besar Bahasa Indonesia.

${ }^{35} \mathrm{Al}$ Ikhwanul Muslimun adalah organisasi yang banyak dipengaruhi oleh pemikiran Hasan Al Banna (1906-1949 M). Bahkan, ia menjadi pendiri dari organisasi ini pada April 1928 yang menghidupkan kembali pemikiran Jamaluddin Al-Afghani, Muhammad Abduh, dan Rasyid Ridha. Sedangkan salafi adalah kelompok yang banyak dipengaruhi oleh Muhammad bin Abdul Wahab.

${ }^{36}$ Berbeda dalam nama dan bahasa, namun bersatu dalam bentuk dan tujuan muhtalilifah al Asma' wa al lughat Muttahidah al Asykal wa al aghrad adalah selogan pergerakan tersebut. 
inilah yang menjadi tiang utama gerakan jihadi. Pengikut gerakan ini sebagian besar adalah alumni Afgan, Moro dan Chechnya. ${ }^{37}$

Hiariej menyebutkan bahwa Afganistan menjadi salah satu tempat selain Mindanao bagi Mayoritas tokoh utama gerakan jihad untuk memperoleh keterampilan menggunakan senjata dan alat perang. Mereka juga mendapatkan pengetahuan tentang taktik dan strategi di medan tempur.Menariknya, Hiariej mengemukakan bahwa para aktivis radikal tersebut menghabiskan, barangkali, waktu paling bermakna dalam hidupnya sebagaiaktivis radikal di Afghanistan. ${ }^{38}$ Waktu tersebut bisa saja sepanjang hidup, didedikasikan oleh aktivis ikhwan sayap kanan dan salafi sayap radikal ini.

Pertemuan ikhwan sayap kanan dan salafi sayap radikal, menurut Razi,bermula pada tahun 1960-an yang mana kemajuan Arab Saudi dalam peningkatan produksi minyak membuat kerajaan memerlukan infrastruktur dan sumber daya manusia yang berkualitas. Kelompok Ikhwanul Muslimin adalah kelompok yang menjadi rujukan dalam pengembangan pendidikan Arab Saudi ketika itu. Kelompok ini sejalan dengan paham Wahabi dalam hal aqidah dan peribadatan, namun tidak dalam hal politik dan pemerintahan. ${ }^{39}$ Meski keduanya berbeda dalam hal tertentu, akan tetapi bukan berarti keduanya tidak dapat menyatu. Serangan Uni Soviet ke Afganistan telah menggiring kedua kelompok ini untuk menyatukan kekuatan. Para ulama Wahabi sepakat untuk menyatukan dukungan dengan kelompok Al Ikhwanul Muslimun (yang kemudian disebut AlShahwah al-Islamiyyah)dan mendukung Afganistan. ${ }^{40}$ Pertempuran mendukung Afganistan inilah yang menjadi cikal bakal lahirnya wabah jihadi.

\footnotetext{
${ }^{37}$ Salafi sendiri dikelompokkan menjadi dua, yakni salafi dakwah dan salafi sururi. Akan tetapi, dari dua ini kemudian berkembang menjadi salafi jihadi. "Gerakan Islam Transnasional dan Pengaruhnya di Indonesia,"

${ }^{38}$ Eric Hiariej, “Aksi Dan Identitas Kolektif Gerakan Islam Radikal Di Indonesia,” 6.

${ }^{39}$ Baca juga Fahrur Razi, "Global Salafi Jihadi Tantangan Masa Depan Islam Indonesia," 6.

${ }^{40}$ Lebih lanjut, Razi melaporkan bahwa dukungan kedua kelompok ini sejalan dengan politik internasional Arab Saudi. Terlepas dari pada itu, penyatuan dua kelompok tidak menghambat Al-Shahwah al-Islamiyyah dalam mendekatkan diri pada pemikiran Sayyid Qutub guna menaikkan semangat jihad. Langkah ini kemudian semakin mengintimkan hubungan kedua kelompok di atas yang pada akhirnya terjadilah perkawinan gagasan antara Ikhwanul Muslimin dengan pemikiran Sayyid Qutub dengan Wahabi. Perkawinan kedua kelompok ini kemudian melahirkan Salafi Jihadis di bawah pimpinan orang-orang seperti Abdullah 'Azzam, Mullah Umar dan Osamah bin Laden. Fahrur Razi, "Global Salafi Jihadi Tantangan Masa Depan Islam Indonesia,” 8.
} 
Peristiwa ini kemudian membuat sebuah perubahan yang sangat fundamental. Awal mula kemunculan kelompok salafi wahabi adalah murni untuk kegiatan dakwah. Yakni, gerakan yang berkeinginan untuk kembali kepada ajaran Al-Quran dan Hadis. Keinginan ini kemudian diramu sedemikian rupa, hingga mengimplementasikannya melalui sebuah ajaran yang dikenal dengan pemurnian aqidah. ${ }^{41}$ Akan tetapi, seiring dengan perkembangan dan menguatnya pengaruh Wahabi kelompok salafi kemudian terbelah menjadi kelompok salafi dakwah dan kelompok salafi sayap radikal. ${ }^{42}$ Kelompok salafi sayap radikal inilah kemudian bertransformasi menjadi sebuah gerakan yang dikenal dengan sebutan Salafi Jihadis.

Salafi Jihadis adalah perpaduan dari dua model pemahaman, yaitu Wahabisme dalam akidah dan Qutbisme dalam gerakan. ${ }^{43}$ Kelompok ini memiliki karakteristik menjustifikasi penggunaan kekerasan dan terorisme untuk mencapai tujuan politiknya, yaitu mendirikan struktur pemerintahan Islam. ${ }^{44}$ Oleh karenanya, sebagai wadah perjuangan gerakan, Salafi Jihadis sangat fokus dalam membahas isu-isu sosial, budaya, dan politik, akan tetapi gerakan mereka cenderung tidak struktural dengan negara. Hal ini disebabkan pergerakan ideologis akan mengalami kesulitan dalam menyebarkan pengaruhnya apabila langsung berada dalam struktur pemerintahan. ${ }^{45}$

\footnotetext{
${ }^{41}$ Menurut kelompok salafi, Islam dalam tataran ajaran dan praktiknya yang ideal hanya terdapat pada masa Nabi, sahabat hingga tabi' al-tabi'in, selebihnya telah mengalami penambahan dan pengurangan, bahkan menurut kelompok ini telah terkontaminasi oleh berbagai hal yang menimbulkan takhayul, bid'ah, churafat (TBC) -dalam istilah Muhammadiyah. Lebih lanjut Tabroni mengemukakan bahwa Muhammadiyah berhasil menggabungkan watak salafi dan modernisme. Ini terkesan tidak biasa karena salafi yang memiliki kecenderungan literal-tekstual dan anti modern dapat disandingkan dengan modernisme yang menghindari teks, baik Al-Quran maupun Hadis. Lihat dalam Tobroni, "Strategi Kebudayaan Sebagai Alat Dakwah Pada Alaf Ketiga (Bahasa Melayu)," 12 dalam http://tobroni.staff.umm.ac.id/2010/12/01/strategi-kebudayaan-sebagai-alat-dakwahpada-alaf-ketiga-bahasa-melayu/ (diakses pada tanggal 11 September 2014).

${ }^{42}$ Perkembangan kelompok Salafi cukup pesat dalam dunia global. Ini bermula dari bergabungnya kelompok wahabi yang dipopulerkan oleh Muhammad bin Abdul Wahab (1115-1206H) atau (1703-1792M). Ia adalah tokoh sentral dalam gerakan salafi, yang dalam perkembangannya kemudian dikenal sebagai aliran whabi/wahabisme.

${ }^{43} \mathrm{Hal}$ ini disampaikan Razi dalam abstrak penelitiannya. Baca dalam Fahrur Razi, "Global Salafi Jihadi Tantangan Masa Depan Islam Indonesia," 1.

${ }^{44}$ Muhammad Najib Azca, "Yang Muda, Yang Radikal: Refleksi Sosiologis Terhadap Fenomena Radikalisme Kaum Muda Muslim di Indonesia Pasca Orde Baru," 18.

${ }^{45}$ Baca lebih lanjut tentang civil society dalam Ozi Setiadi, Islam dan Civil Society: Pergerakan Hizmet di Indonesia sebagai Tipologi Civil Society Budaya, (Jakarta: Impressa Publishing, 2013).
} 
Salafi Jihadis menolak keras penggunaan produk ideologis Barat, seperti liberalisme, kapitalisme, persamaan gender, demokrasi dan lainnya. Bagi mereka hanya Islam yang bisa menjawab berbagai persoalan kehidupan termasuk dalam bidang sosial dan politik, sehingga tidak ada alternatif lain selain Islam. Berbeda dengan kelompok aktivisme politik Islam yang menggunakan berbagai media yang memungkinkan guna mewujudkan tujuan, termasuk memanfaatkan demokrasi. Ini sejalan dengan apa yang dikemukakan oleh Setiadi bahwa dakwah yang dahulu hanya dipahami sebagai sebuah seruan melalui lisan berkembang menjadi sebuah pergerakan oleh sekelompok orang yang terorganisir. Hasilnya, dakwah dalam bentuk pergerakan muncul tidak hanya dalam bidang sosial-keagamaan melainkan juga dalam bidang politik, pendidikan, ekonomi, dan budaya. ${ }^{46}$ Ini tentunya dengan memanfaatkan segala kemungkinan yang pantas.

Perkembangan kebudayaan Islam berkembang tidak hanya melibatkan satu faktor, akan tetapi dua faktor yang terlibat. Zuhairini menyebut dua faktor tersebut sebagai faktor internal sebagai pembawaan dari Islam itu sendiri dan faktor eksternal sebagai pengaruh dari luar. ${ }^{47}$ Gerakan Islam yang mengusung global jihad sebagai jalan gerakannya seolah menolak pengaruh kuat dari faktor eksternal. Fakta dibalik tergulingnya Muhammad Morsi di Mesir telah berbicara banyak bagaimana keterlibatan Al Ikhwanul Muslimun dalam pemerintahan. Kelompok ini kemudian berupaya mengganti sistem peninggalan Husni Mubarak secara frontal dengan mengabaikan berbagai kepentingan dari luar, seperti kelompok nasionalis sekuler, pendukung mubarak, dan tidak kalah penting adalah pengaruh Barat di Timur Tengah.

Al Ikhwanul Muslimun dan Wahabi sebagai sebuah fokus yang cukup menjadi sorotan bagi lahirnya ideologi radikal di kalangan dunia Islam ternyata bukanlah satu-satunya yang ada di dunia. Pada agama lain, ideologi yang sama juga telah ada. Khaled Abou El Fadl menyebut apa yang dilakukan oleh kaum Wahabi mempunyai kemiripan dengan apa yang dilakukan oleh orang-orang Yahudi, terutama tatkala mereka mengutuk Maimondes. Atau, seperti orang-orang Katolik

\footnotetext{
${ }^{46}$ Ozi Setiadi, "Dakwah dan Civil Society: Analisis Pergerakan Hizmet dalam Perspektif Teori Organisasi," Jurnal Kajian Islam Modern Vol. 1 No. 2 2013/2014, 27. Lebih lanjut, kalangan fundamentalis tidak mau memanfaatkan demokrasi sebagai sarana pengembangan dakwah. Sebaliknya, demokrasi menurut mereka hanya menghambat berdirinya negara Islam sebagai tujuan utama pergerakan politik non-formal. Ini menjadi ciri pergerakan fundentalis-keagamaan, dalam hal ini fundamentalis Islam yang seolah melakukan penyempitan dalam pemaknaan dakwah.

${ }^{47}$ Baca Zuhairini dkk, Sejarah Pendidikan Islam (Jakarta: PT. Bumi Aksara, 2015), Cet. XIII, 88.
} 
saat mereka mengkritik Thomas Aquinas yang dianggap kafir. Pandangan ini mengukuhkan tesis Karen Armstrong yang menyatakan, puritanisme yang melahirkan terorisme bukan hanya monopoli kalangan Muslim saja, tetapi juga dapat ditemukan dalam khazanah agama-agama samawi lainnya, seperti Yahudi dan Kristen. ${ }^{48}$

Meski tidak terekspose terlalu "vulgar", sebagai contoh, beberapa kalangan Yahudi Amerika juga disebut-sebut masuk dalam kelompok radikal. Apalagi orangorang Yahudi Amerika telah menempati posisi-posisi penting dan strategis pada negara itu. ${ }^{49} \mathrm{Hal}$ ini dikarenakan mereka masih memegang teguh kasta, orangorang Yahudi juga menjaga rasnya. Mereka terus-menerus memasukkan "darah baru" ke dalam sistem yang mereka bangun guna menjaga kelestariannya. ${ }^{50}$ Ini menandakan bahwa kelompok radikal akan tetap ada, sebab mereka sendiri yang melestarikan kelompoknya, begitu pula dengan kelompok-kelompok radikal pada agama selain Islam.

Kalangan fundamentalis Katolik, bila dipikirkan lebih dalam, juga terlibat dalam pelestarian ideologi radikal. Nowicka menyebut bahwa kelompok perempuan Katolik, yang menentang kesetaraan jender, berpartisipasi dalam pertemuan di mana instrumen untuk menerapkan kesetaraan jender sedang dibahas dan dipromosikan. Dengan demikian, fundamentalisme Katolik diarusutamakan sebagian oleh perempuan yang bekerja secara aktif melawan hakhak perempuan. Lanjut Nowicka, Beberapa politisi dan pembuat kebijakan sekarang menyerukan kerjasama antara kelompok perempuan feminis dan kelompok perempuan fundamentalis sebagai alasan untuk tidak bertindak di antara mereka yang tidak menginginkan seseorang, yang tidak menginginkan gerakan perempuan feminis yang aktif, untuk mempengaruhi kehidupan publik. ${ }^{51}$

${ }^{48}$ A.M. Hendropriyono, Terorisme Fundamentalisme Kristen, Yahudi, Islam (Jakarta: PT. Kompas Media Utara, 2009), xi.

${ }^{49} 45 \%$ dari 40 orang terkaya Amerika adalah Yahudi. 1/3 orang terkaya Amerika adalah Yahudi. 20\% profesor di berbagai universitas terkemuka adalah Yahudi. 40\% pengacara dan berbagai firma hukum di Amerika dikuasai oleh Yahudi. 25\% pemenang hadiah nobel science adalah Yahudi. Dan setengah dari jumlah penduduk Yahudi di dunia berada di Amerika. Ansara, "Dominasi Yahudi Di Amerika," Kompasiana, 11 Oktober 2010 dalam https://www.kompasiana.com/anniesabri/dominasi-yahudi-diamerika_55003285a33311537 35100ec (diakses pada tanggal 07 Desember 2017).

${ }^{50}$ David Waldstreicher, "Radicalism, Religion, Jewishness: The Case of Emma Goldman," 75.

${ }^{51}$ Pendapat Nowicka ini didasarkan pada sebuah penelitian bahwa setelah runtuhnya kondisi komunisme, sosial dan politik di Polandia menyebabkan perkembangan fundamentalisme Katolik Roma, yang dihasilkan oleh Episkopat Polandia, yang bercita-cita 
Artinya, kalangan fundamentalis Katolik berkeinginan agar kehidupan "keperempuan-an" berjalan sebagaimana yang berlaku dalam pemahaman mereka, tanpa melibatkan kalangan feminis. Berbeda dengan kalangan feminis yang sibuk dengan keinginan kesetaraan gender, atas hak dan kewajiban, antara laki-laki dengan perempuan.

\section{E. Terorisme Keagamaan}

Terorisme adalah suatu tindakan yang didasari sistem nilai dan cara pandang dunia, sehingga untuk memahaminya memerlukan suatu kerangka dan metodologi pemikiran yang biasa digunakan dalam tradisi filsafat. ${ }^{52}$ Terorisme erat kaitannya dengan fundamentalisme dan radikalisme keagamaan. Hendropriyono menyebut bahwa masyarakat yang telah tercemari fundamentalisme dan radikalisme keagamaan adalah lahan subur bagi perkembangan terorisme keagamaan..$^{53}$ Ini disebabkan terorisme hanya bisa tumbuh subur dalam kondisi dan lokasi tertentu yang dapat mendukung perkembangannya. Masyarakat yang telah tercemari paham fundamentalisme dan radikalisme keagamaan adalah salah satu dari sekian banyak lahan subur yang dapat ditanami bagi perkembangan terorisme keagamaan.

Elemen kesatuan internal ini diciptakan melalui dua proses framing(pembentukan) : pertama, dengan mendefenisikan siapa dirinya dan siapa musuhnya, dan, kedua, dengan menguraikan persoalan-persoalan yang tengah dihadapi dan bagaimana mengatasinya. Tapi tidak berarti gerakan Islam radikal adalah sebuah kesatuan yang utuh dan kompak. ${ }^{54}$ Meski dari luar terlihat begitu solid dalam menghadapi "musuh bersama", namun secara internal tetap terdapat pergolakan dalam menentukan arah, tindakan, bahkan tujuan mereka. ${ }^{55}$

untuk memainkan peran politik, diperkuat oleh 'Paus Polandia'. Ia juga menyoroti kampanye politik Gereja tentang aborsi, kontrasepsi dan pendidikan seks. Lihat lebih lanjut dalam Wanda Nowicka, "Roman Catholic Fundamentalism against Women's Reproductive Rights in Poland," Reproductive Health Matters, Vol. 4, No. 8, Fundamentalism, Women's Empowerment and Reproductive Rights (Nov., 1996), 21.

${ }^{52}$ A.M. Hendropriyono, Terorisme Fundamentalisme Kristen, Yahudi, Islam, 1.

${ }^{53}$ A.M. Hendroprioyono, Terorisme: Fundamentalis Kristen, Yahudi dan Islam (Jakarta: Buku Kompas, 2009), hlm. 13 dalam Badan Nasional Penanggulangan Terorisme (BNPT), "Strategi Menghadapi Paham Radikalisme Terorisme - ISIS," 1, dalam http://belmawa.ristekdikti.go.id/wp-content/uploads/2016/12/Strategi-MenghadapiPaham-Radikalisme-Terorisme.pdf (diakses pada tanggal 11 September 2017).

${ }^{54}$ Eric Hiariej, “Aksi Dan Identitas Kolektif Gerakan Islam Radikal Di Indonesia,” 10.

${ }^{55}$ Pergolakan terjadi dalam menentukan berbagai hal yang hendak dilakukan. Termasuk strategi-strategi guna mencapai tujuan. Akan tetapi, dalam berbagai perumusan tentang 
Kelompok Islam radikal mendefinisikan dirinya dengan berbagai nama. Mulai dari menyebut dirinya sebagai pengikut tradisi ke-nabi-an, mujahidin, atau berbagai komunitas Islam yang lain. Meski berbeda nama, namun mereka menganggap dirinya sebagai pembela Islam. Artinya, pembela ajaran-ajaran Islam yang terkontaminasi dan pembela orang-orang Muslim yang diserang, bukan pembela Islam yang digunakan sebagai nama organisasi Fron Pembela Islam (FPI). ${ }^{56} \mathrm{Hal}$ ini mengandung makna tersirat bahwa pembelaan tersebut terjadi karena anggapan Islam dan umatnya sedang terzolimi, sehingga butuh dibela. Oleh karenanya, wajib bagi setiap muslim untuk berjihad dan melakukan pembelaan.

Jamaah Islamiyah atau jamiat Islami didirikan di anak benua India-Pakistan pada tahun 1941 oleh Abu A'la al-Maududi (1903-1979). Munculnya organisasi ini juga bermula dari keinginan yang sama dengan kelompok Islam yang lain, yakni mensyiarkan Islam. Bermula dari keinginan untuk memperbaiki aqidah umat, kemudian melebar hingga ekonomi dan memperbaiki sistem pemerintahan sesuai dengan ajaran Islam. Akan tetapi, Afrizal menyebut, dalam perkembangannya mendapatkan perlawanan dari kelompok sekuler Pakistan, hingga dianggap sebagai kelompok teroris oleh Amerika dan sekutunya. ${ }^{57} \mathrm{Hal}$ ini dikarenakan implementasi pergerakan yang berbeda dengan apa yang dijalankan dengan kelompok sekuler serta Amerika dan sekutunya. Lebih lanjut, keinginan untuk mendirikan negara Islam tetap tidak dapat dipisahkan dari pergerakan ini.

Gerakan Nurcu dan Hizmetasal Turki juga menjadi sorotan dalam perkembangan demokrasi modern Islam saat ini. ${ }^{58}$ Gerakan nurcu diinspirasi oleh

hal yang akan dikerjakan itu terkadang juga terdapat ketidakcocokan antara satu dengan yang lain, sehinggga tidak menutup kemungkinan ketidakcocokan tersebut meluas menjadi perpecahan dalam sebuah pergerakan. Al-Qaeda dan ISIS adalah contoh yang mungkin dapat dilihat. ISIS yang merupakan sempalan dari Al-Qaeda yang merasa memiliki perbedaan garis perjuangan yang lebih khusus di bandingkan dengan Al-Qaeda yang ingin mendirikan negara Islam tanpa adanya spesifikasi. Sedangkan ISIS menginginkan negara Islam pada Iraq dan Syiria.

${ }^{56}$ Eric Hiariej, “Aksi Dan Identitas Kolektif Gerakan Islam Radikal Di Indonesia,” 11.

${ }^{57}$ Jhon Afrizal, "GERAKAN SOSIAL POLITIK ISLAM DUNIA (Asas Perubahan Skenario Politik Negara)," 145.

${ }^{58}$ Nurcu (Nurculuk) secara etimologi berasal dari kata nur-cu yang berarti ahli cahaya, sedangkan secara terminologi yaitu sebuah pergerakan dengan strategi memindahkan masyarakat dengan meningkatkan kesadaran individu dan "melindungi" manusia dari "tidak beriman", begitu pula dengan sekolah dari paham fanatisme. Lihat dalam M. Hakan Yavuz, "Towards an Islamic Liberalism?: The Nurcu Movement and Fethullah Gülen", Middle East Journal, Vol. 53, No. 4 (Autumn,1999), pp. 584-605, Middle East Institute, http://www.jstor.org/stable/4329392 (diakses tanggal 19/03/2012). 
Said Nursi(1876-1960). ${ }^{59}$ Pada perkembangannya gerakan ini diikuti oleh berbagai pihak yang simpati kepada Nursi, termasuk Muhammed Fethullah Gülen. Gülen kemudian mengembangkan sendiri sebuah gerakan yang didasari atas ide-ide yang dikemukakan oleh Nursi. Bersama dengan kelompoknya,Gülen membangun sebuah gerakan yang dikenal sebagai gerakan hizmet.

Hizmet (bahasa Turki) dalam bahasa Arab disebut khidmah,berarti pelayanan. ${ }^{60}$ Secara sederhana hizmet diartikan sebagai kesadaran untuk menghamba kepada Allah swt. yang diwujudkan melalui pengabdian dan pelayanan kepada sesama guna mendapatkan Ridâa-Nya. Istilah ini berkontribusi secara luas dan berpartisipasi dalam kehidupan sosial-ekonomi, tidak hanya dalam konteks Muslim, tetapi juga dalam konteks non-Muslim. ${ }^{61}$ Atas dasar inilah Gülen dan pengikutnya mengembangkan sebuah pergerakan yang mereka sebut sebagai pergerakan hizmet.

Pergerakan hizmet memfokuskan diri pada pendidikan, antar budaya dan pelayanan antar agama. ${ }^{62}$ Promosi, dialog yang intensif, dan kerjasama peradaban dibangun tidak hanya dengan sesama umat Islam, tetapi juga dengan umat agama lain. ${ }^{63}$ Di Turki sendiri, gerakan ini sukses membangun kedekatan dengan Adalet ve Kalkinma Partisi (AKP). Partai pimpinan Racep Tayyib Erdoġan ini mendapatkan

\footnotetext{
${ }^{59}$ Said Nursi adalah pemikir Islam yang melahirkan karya fenomenal yang dikenal dengan Risale-i Nur. Lebih lanjut lihat dalam Sükran Vahide, Biografi Itelektual Bediuzzaman Said Nursi: Transformasi Dinasti Utsmani Menjadi Republik Turki (Jakarta: Anatolia,2007).

${ }^{60}$ Ahmad Sunarto, Kamus Alfikr (Surabaya: Halim Jaya, 2007), cet. III.

${ }^{61}$ Erkan Togoslu, "Hizmet: from Futuwwa Tradition to the Emergence of Movement in Public Space", 15 November 2008, Fethullah Gülen Chair, www.fethullahGülenchair.com(diakses tanggal 9 November 2011). Lebih lanjut Enayat mengatakan bahwa pembatasan yang ditempatkan oleh syarîah dalam kebenaran nonmuslim tidak permanen dan tidak dapat dihilangkan karena non-muslim selalu memiliki pemikiran untuk masuk ke dalam agama Islam, dan dengan cara demikian mereka mengatasi ketidakmampuan politik. Hamid Enayat, Modern Islamic Political Thought (Kuala Lumpur: The Macmillan Press, 2001), 189.

${ }^{62}$ Lihat dalam Muhammed Çetin, "The Contribution of Islamic Schoolarship to Democracy", 105, disampaikan pada konferensi The Significance of Education for the Future: The Gülen Model of Education, UIN Syarif Hidayatullah Jakarta, Jakarta-Indonesia, 19-21 Oktober 2010. Berbeda dengan Yavuz yang menyebutkan bahwa pergerakan hizmet lebih menekankan negara-sentris nasionalisme Turki, dan pasar bebas, meskipun ia juga menyebutkan pendidikan sebagai salah satu fokus pergerakan. Lihat M. Hakan Yavuz, "Nasil bir Thrkiye" (What Type of Turkey?), Milliyet (Istanbul), 11 August 1997, dalam M. Hakan Yavuz, "Towards an Islamic Liberalism?".

${ }^{63}$ Baca juga Ozi Setiadi, "Perspektif Fethullah Gülen Tentang Dialog Dan Toleransi Sebagai Resolusi Konflik," LEEGALITĖ. Jurnal Perundang Undangan dan Hukum Pidana Islam, Volume I. No. 02. Juli-Desember 2016M/1437H.
} 
dukungan dari orang-orang hizmet, hingga Ahmad Syafi'i Ma'arif menyebut beberapa kalangan khawatir dengan pergerakan hizmet dan para pengikut Gülen mengenai kedekatan mereka dengan AKP, dan menyebutnya sebagai "negara dalam negara". ${ }^{64}$ Sayangnya, kedekatan ini tidak berlangsung lama. Pengaruh gerakan hizmet yang semakin kuat membuat gerakan ini tak mau terlibat dalam berbagai skandal pemerintah, utamanya korupsi.

Tepat saat kudeta gagal yang dilakukan terhadap Erdogan oleh segelintir kalangan militer yang tidak didukung oleh mayoritas sipil, Erdoġan menuding dalang dibalik itu semua adalah kelompok hizmet. Kemampuan gerakan ini yang mampu merangsek masuk dalam berbagai lini pemerintahan Turki menjadi sebuah alat bukti bagi Erdogan untuk melegitimasi apa yang dikemukakan olehnya. Erdoġan dan pemerintahannya menganggap pergerakan hizmet sebagai ancaman karena telah merasuk di berbagai lini, termasuk kepolisian dan kehakiman. Oleh sebab itu, pergerakan hizmet dianggap sebuah ancaman yang menakutkan yang bisa mengkudeta pemerintahan Turki kapan saja. ${ }^{65}$ Yavuz menambahkan pergerakan hizmet juga didukung oleh jaringan bisnis yang kuat, ${ }^{66}$ sehingga mandiri dari pemerintah. ${ }^{67}$

Pergerakan hizmet dan Gülen dituduh sebagai teroris, dan diberi label dengan istilah Fethullah Terorist Organization (FETO). Ini dikuatkan dengan pengakuan beberapa jendral dalam upaya kudeta yang gagal, seperti Huluki Akar (Kepala Staf Jenderal), Levent Turkkan (Letnan Kolonel), Mithat Aynaci (Mantan Manager

\footnotetext{
${ }^{64}$ Ahmad Syafii Ma'arif, "Fethullah Gülen dan Misi Kemanusiaannya [2]", Republika, Selasa, 5 Juni 2012. Lihat juga Ari, "Fethullah Gulen, Sang Perajut Jejaring Dunia Islam", dalam http://www.suaramedia.com/sejarah/sejarah-islam/23787-fethullah-gulen-sangperajut-jejaring-dunia-islam.html, (diakses pada tanggal 18/06/2012).

${ }^{65}$ Murat Tokay, "Gülen Movement Becomes New Target of Scaremongers," Today's Zaman, 12 April 2011, http://www.todayszaman.com/news-240813-news-analysis-gulenmovement-becomes-new-target-of-scaremongers.html (diakses pada tanggal 17 Nopember 2011). Pemberitaan mengenai pergerakan hizmet sebagai ancaman ternyata tidak hanya diberitakan oleh koran Turki saja, melainkan juga di Indonesia isu tentang pergerakan hizmet sebagai ancaman juga menjadi topik hangat. Baca juga Editorial, "Fethullah Gulen, Perajut Jejaring Dunia Islam".

${ }^{66}$ M. Hakan Yavuz, "Nasil bir Thrkiye" (What Type of Turkey?), Milliyet (Istanbul), (11 August 1997), dalam M. Hakan Yavuz, "Towards an Islamic Liberalism?: The Nurcu Movement and Fethullah Gülen," Middle East Journal, Vol. 53, No. 4 (Autumn, 1999), 604, http://www.jstor.org/stable/4329392 (diakses tanggal 19 Maret 2012).

${ }^{67}$ Baca Ozi Setiadi, "Islam dan Pergerakan Civil Society Kebudayaan Transnasional Hizmet di Indonesia," Jurnal Kordinat - XVI No. 1 April 2017.
} 
Keamanan), dan Fatih Celaleddin Sagir (Brigadir Jenderal). ${ }^{68}$ Meski semua petinggi militer tersebut mengaku memiliki hubungan dengan FETO, namun hingga tulisan ini dibuat belum ditemukan bukti kuat bahwa Gülen memerintahkan untuk melakukan kudeta.

Terorisme keagamaan sering kali bersentuhan dengan pemerintahan domestik. Bahkan, gerakan terorisme yang mengatasnamakan agama tidak hanya menjadi "musuh" domestik sebuah negara, melainkan juga telah menjadi musuh internasional. Jaringan-jaringan yang dibuat oleh para teroris menembus batasbatas kenegaraan, sehingga tidak menutup kemungkinan aksi teroris yang satu terkait dengan yang lain. Aksi ini tentunya akan berdampak lebih luas dan menimbulkan akibat yang tidak bisa dianggap enteng.

ISIS adalah sebuah bukti bagaimana aksi terorisme telah membuat masyarakat internasional khawatir. Tidak hanya di Irak dan Syiriah sebagai tempat dimana gerakan ini lahir, melainkan di berbagai negara di dunia.Banyak pelaku terorisme yang berbaiat dengan ISIS dan kemudian menyebut diri mereka adalah bagian dari ISIS itu sendiri. Hal ini tentu menjadi problematika tersendiri, yang tidak hanya mengusik individu domestik, tetapi juga masyarakat internasional secara luas.

\section{F. Problem Keagamaan yang Timbul Akibat Ideologi Radikal, Global Jihad dan Terorisme}

Teori-teori gerakan sosial baru (GSB) menyebut identitas kolektif melahirkan rasa senasib sepenanggungan, rasa menghadapi musuh bersama dan rasa memiliki tujuan bersama—yang membentuk "ke-kita-an" dari setiap gerakan sosial—bukan saja menentukan bentuk dan berhasil tidaknya sebuah aksi, tapi juga bisa dipandang sebagai tujuan gerakan itu sendiri. ${ }^{69}$ Giddens menyebutkan bahwa gerakan sosial sebagai suatu upaya kolektif untuk mengejar suatu kepentingan berasama, atau mencapai tujuan bersama melalui tindakan kolektif di luar lingkup lembaga-lembaga yang mapan. ${ }^{70}$ Sedangkan Sidney Tarrow mengemukakan gerakan sosial adalah tantangan-tantangan kolektif yang didasarkan pada tujuantujuan bersama dan solidaritas sosial, dalam interaksi yang berkelanjutan dengan

\footnotetext{
${ }^{68}$ Republika Online, "Ini Bukti-Bukti Keterlibatan Gülen dalam Kudeta Versi Otoritas Turki," (diakses pada tanggal 26 September 2017).

${ }^{69}$ Eric Hiariej, "Aksi Dan Identitas Kolektif Gerakan Islam Radikal Di Indonesia,"2, dalam http://mprk.ugm.ac.id/wp-content/uploads/2014/06/Hiariej-Aksi-dan-IdentitiasKolektif-Gerakan-Islam-Radikal-di-Indonesia.pdf (diakses pada tanggal 07 September 2017).

${ }^{70}$ Fadhillah Putra dkk, Gerakan Sosial, Konsep, Strategi,Aktor, Hambatan Dan Tantangan Gerakan Sosial Di Indonesia (Malang: PlaCID’s dan Averroes Press, 2006), 1.
} 
para elit, penentang dan pemegang wewenang. ${ }^{11}$ Terdapat berbagai hal yang dilakukan oleh para pelaku gerakan sosial dalam rangka mewujudkan tujuan dan soliditas sosial. Edi Swasono meyebut kerjasama bermula dari paham kebersamaan, saling bergotong royong demi mencapai sebaik-baik kepentingan bersama (mutual interest). ${ }^{72}$ Berbagai pendapat di atas menandakan bahwa sebenarnya agama tidak mendapatkan terlalu banyak keuntungan atas aksi-aksi yang dilakukan, mengingat tujuan yang diingakan bersifat subjektif. Sebaliknya, penganut agama adalah yang paling banyak dirugikan atas aksi-aksi radikalisme, global jihad, dan terorisme.

Tuduhan agama sebagai sumber radikalisme, jihad, dan terorisme diberikan oleh orang-orang di luar agama yang dianut oleh para radikalis, jihadis, dan teroris. Ini mengakibatkan orang yang menganut agama yang sama dengan para pelaku radikal, jihad dan teror menerima dampak buruk atas tindakan yang dilakukan oleh mereka. Akibatnya, bukan hanya terdiskriminasi, tetapi juga terdeskriditkan. Lebih buruk lagi, dianggap pula sebagai musuh bersama yang harus diperangi.

Anggapan demikian tentunya akan memberikan efek yang tidak baik. Memusuhi dan keinginan untuk memerangi kelompok yang terdisikriminasi dan terdeskriditkan dapat menimbulkan perlawanan oleh kelompok itu. Aksi terorisme menjadi salah satu cara untuk membalas apa yang telah diterima oleh kelompok yang terdiskriminasi. Setidaknya, sebagaimana yang diungkapkan oleh Hendropriyono, mereka dapat melakukan aksi tetorisme dengan mendasarinya pada tiga hal. Pertama, faham dan ideologi terorisme. Kedua, gerakan dan jaringan yang mengembangkan faham keagamaan yang dapat melahirkan para teroris atau yang mempunyai keberanian dan kepercayaan diri untuk melakukan tindakan terorisme. Ketiga, tindakan atau aksi terorisme tersebut. ${ }^{73}$

Berbagai tindakan yang dilakukan sebagai sebuah bentuk perlawanan akan mengakibatkan disintergrasi umat beragama. Saling curiga dan tidak percaya dapat muncul bak matahari terbit yang semakin panas saat ia meninggi. Potensi konflik dan perpecahan semakin terbuka lebar akibat dari ulah para pelaku

${ }^{71}$ Baca lebih lanjut David S. Meyer and Sidney Tarrow, "The Social Movement Society: Contentious Politics for a New Century," The American Political Science Review, Vol. 96, No. 2 (Jun., 2002), 446-448 dalam http://www.jstor.org/stable/3118087(diakses pada tanggal 18 Desember 2017).

${ }^{72}$ Sri-Edi Swasono, Keindonesiaan: Demokrasi Ekonomi, Keberdaulatan, dan Kemandirian, 30.

${ }^{73}$ A.M. Hendropriyono, Terorisme Fundamentalisme Kristen, Yahudi, Islam, xix. 
radikalisme, jihad, dan terorisme. Hal ini tidak hanya terjadi bagi umat antar agama, melainkan juga dengan sesama umat agama sendiri.

\section{G. Penutup}

Ideologi radikal, global jihad, dan terorisme keagamaan adalah hal yang terkait satu dengan yang lain.Ini disebabkan jihad tidak bisa lahir tanpa ideologi radikal, begitu pula dengan terorisme yang dapat tumbuh dimana saja dengan doktrin jihad.

Ideologi radikal dapat melahirkan radikalisme, dan radikalisme seringkali dikaitkan dengan praktik keagamaan seseorang. Agama acapkali dijadikan sebagai alat guna membenarkan dan menjadi jalan bagi radikalisme. Keinginan untuk merubah keadaan secara drastis dengan menggunakan berbagai cara menjadi hal yang tidak tabu bagi kalangan radikalis untuk menggunakan agama. Ia menjadi alat yang ampuh karena bersinggungan langsung dengan kepercayaan penganutnya dengan Sang Pencipta, sehingga legitimasi kekerasan atas nama agama dapat dilakukan setiap saat.

Global jihad adalah salah satu jalan implementasi aktivitas radikalisme. Semakin radikal seseorang dalam keinginannya membuat sebuah perubahan yang fundamental berdasarkan apa yang ia yakini, maka jihad adalah jalan yang nyata baginya untuk dilakukan. Global jihad memanfaatkan sumber daya transnasional yang mereka miliki. Sedangkan terorisme keagamaan merupakan bentuk pemanfaatan agama sebagai alat legitimasi tindakan teror.

Aksi-aksi radikalisme, global jihad, dan terorisme berdampak langsung bagi agama dan penganutnya. Agama yang dianut oleh para radikalis, jihadis, dan teroris akan dianggap sebagai agama yang mengajarkan tindakan teror, jihad, dan radikal. Pemeluknya pun akan dicap sebagai umat yang intoleran, sebab memaksakan keinginannya dengan menggunakan tiga hal tersebut. Lebih lanjut, ini dapat menyebabkan permusuhan dan perpecahan tidak hanya antar umat beragama, tetapi juga internal pemeluk agama. Sebab mayoritas pemeluk agama tidak sependapat dengan apa yang dilakukan oleh orang-orang yang menganggap dirinya mendapat perintah suci dari Tuhan, yakni para radikalis, jihadis, dan teroris. 


\section{DAFTAR PUSTAKA}

Afrizal, Jhon. "Gerakan Sosial Politik Islam Dunia: Asas Perubahan Skenario Politik Negara,” Jurnal Sosial Budaya Vol. 9 No. 1 Januari-Juli 2012 dalam https://media.neliti.com/media/publications/40436-ID-gerakan-sosialpolitik-islam-dunia-asas-perubahan-skenario-politik-negara.pdf (diakses pada tanggal 07 September 2017).

Ari, "Fethullah Gulen, Sang Perajut Jejaring Dunia Islam", http://www.suaramedia.com/sejarah/sejarah-islam/23787-fethullah-gulensang-perajut-jejaring-dunia-islam.html, (diakses pada tanggal 18 Juni 2012).

Azca, Muhammad Najib. "Yang Muda, Yang Radikal: Refleksi Sosiologis Terhadap Fenomena Radikalisme Kaum Muda Muslim di Indonesia Pasca Orde Baru,”.

Badan Nasional Penanggulangan Terorisme (BNPT), "Strategi Menghadapi Paham Radikalisme Terorisme - ISIS," http://belmawa.ristekdikti.go.id/wpcontent/uploads/2016/12/Strategi-Menghadapi-Paham-Radikalisme-

Terorisme.pdf (diakses pada tanggal 11 September 2017).

Enayat, Hamid. Modern Islamic Political Thought. Kuala Lumpur: The Macmillan Press, 2001.

Ghufron, Fathorrahman. "Radikalisme dan Politik Identitas," 05 Mei 2017 http://nasional.kompas.com/read/2017/05/05/19170871/radikalisme.dan. politik.identitas (diakses pada tanggal 11 September 2017).

Hendropriyono, A.M. Terorisme Fundamentalisme Kristen, Yahudi, Islam. Jakarta: PT. Kompas Media Utara, 2009.

Hiariej, Eric. "Aksi Dan Identitas Kolektif Gerakan Islam Radikal Di Indonesia," http://mprk.ugm.ac.id/wp-content/uploads/2014/06/Hiariej-Aksi-dan-

Identitias-Kolektif-Gerakan-Islam-Radikal-di-Indonesia.pdf (diakses pada tanggal 07 September 2017).

Maarif Institute For Cultural Humanity, http://maarifinstitute.org/maariffellowship/?gclid=CPy3qayMktYCFdMRaAod6VwNpA (diakses pada tanggal 07 September 2017).

Ma'arif, Ahmad Syafii. "Fethullah Gülen dan Misi Kemanusiaannya [2]”, Republika, Selasa, 5 Juni 2012.

Meyer, David S. and Sidney Tarrow, "The Social Movement Society: Contentious Politics for a New Century," The American Political Science Review, Vol. 96, No. 2 (Jun., 2002), 446-448 http://www.jstor.org/stable/3118087(diakses pada tanggal 18 Desember 2017).

NN.Islam in the Contemporary World-2. New Jersey: Tughra Books, 2009.

Nowicka, Wanda. "Roman Catholic Fundamentalism against Women's Reproductive Rights in Poland," Reproductive Health Matters, Vol. 4, No. 8, Fundamentalism, Women's Empowerment and Reproductive Rights (Nov., 1996). 
Rakhmatulloh. "Sejarah Munculnya Radikalisme," Kamis, 12 Mei 2016.https://nasional.sindonews.com/read/1107997/14/sejarah-

munculnya-radikalisme-1463048982 (diakses pada tanggal 11 September 2017).

Republika Online, "Ini Bukti-Bukti Keterlibatan Gülen dalam Kudeta Versi Otoritas Turki," (diakses pada tanggal 26 September 2017).

Rodin, Dede. "ISLAM DAN RADIKALISME: Telaah atas Ayat-ayat "Kekerasan" dalam al-Qur'an," Addin, Vol. 10, No. 1, Februari 2016 http://journal.stainkudus.ac.id/index.php/Addin/article/download/1128/1 057 (diakses pada tanggal 11 September 2017).

Setiadi, Ozi. Islam dan Civil Society: Pergerakan Hizmet di Indonesia sebagai Tipologi Civil Society Budaya. Jakarta: Impressa Publishing, 2013.

"Dakwah dan Civil Society: Analisis Pergerakan Hizmet dalam Perspektif Teori Organisasi," Jurnal Kajian Islam Modern Vol. 1 No. 2 2013/2014.

"Islam dan Pergerakan Civil Society Kebudayaan Transnasional Hizmet di Indonesia," Jurnal Kordinat - XVI No. 1 April 2017.

"Perspektif Fethullah Gülen Tentang Dialog Dan Toleransi Sebagai Resolusi Konflik," LEEGALITÉ. Jurnal Perundang Undangan dan Hukum Pidana Islam, Volume I. No. 02. Juli-Desember 2016M/1437H.

Suhelmi, Ahmad. Pemikiran Politik Barat: Kajian Sejarah Perkembangan Pemikiran Negara, Masyarakat dan Kekuasaan. Jakarta: PT. Gramedia Pustaka Utama, 2004. Cet. II.

Sunarto, Ahmad. Kamus Alfikr. Surabaya: Halim Jaya, 2007. cet. III.

Swasono, Sri-Edi. Keindonesiaan: Demokrasi Ekonomi, Keberdaulatan, dan Kemandirian. Yogyakarta: Ust Press, 2015.

Tobroni, "Strategi Kebudayaan Sebagai Alat Dakwah Pada Alaf Ketiga (Bahasa Melayu)," http://tobroni.staff.umm.ac.id/2010/12/01/strategi-kebudayaansebagai-alat-dakwah-pada-alaf-ketiga-bahasa-melayu/ (diakses pada tanggal 11 September 2014).

Togoslu, Erkan. "Hizmet: from Futuwwa Tradition to the Emergence of Movement in Public Space", 15 November 2008, Fethullah Gülen Chair, www.fethullahGülenchair.com(diakses tanggal 9 November 2011).

Tokay, Murat. "Gülen Movement Becomes New Target of Scaremongers," Today's Zaman, 12 April 2011, http://www.todayszaman.com/news-240813-newsanalysis-gulen-movement-becomes-new-target-of-scaremongers.html (diakses pada tanggal 17 Nopember 2011).

Ummah, Sun Choirol. "Akar Radikalisme Islam Di Indonesia," Humanika, No. 12 September 2012 https://media.neliti.com/media/publications/18118-IDakar-radikalisme-islam-di-indonesia.pdf (diakses pada tanggal 11 September 2017).

Vahide, Sükran. Biografi Itelektual Bediuzzaman Said Nursi: Transformasi Dinasti Utsmani Menjadi Republik Turki. Jakarta: Anatolia, 2007. 
Wibowo, I. Negara dan Bandit Demokrasi. PT. Kompas Media Nusantara, 2011.

Waldstreicher, David. "Radicalism, Religion, Jewishness: The Case of Emma Goldman," American Jewish History 80, no. 1 (1990).

Yavuz, M. Hakan. "Towards an Islamic Liberalism?: The Nurcu Movement and Fethullah Gülen", Middle East Journal, Vol. 53, No. 4 (Autumn,1999), http://www.jstor.org/stable/4329392 (diakses tanggal 19/03/2012).

Zuhairini dkk.Sejarah Pendidikan Islam.Jakarta: PT. Bumi Aksara, 2015. Cet. XIII. 